\title{
Effect of partial substitution of wheat flour with Moringa oleifera leaf powder on physical, nutritional, antioxidant and antidiabetic properties of cookies
}

Aanuoluwapo Patricia Fapetu, Kayode Olayele Karigidi ${ }^{*}$ C Emmanuel Sina Akintimehin, Tomilayo Olawuwo and Foluso Olutope Adetuyi

\begin{abstract}
Background: Moringa oleifera leaf is a prominent leaf in folk medicine used to treat many diseases including diabetes mellitus. This study is aimed at determining the effects of substitution of wheat flour with Moringa oleifera leaf powder (MOLP) on physical, nutritional, bioactive, antioxidant and antidiabetic properties of cookies. Wheat flour was substituted with MOLP (2.5\%, 5\% and 10\%) in the baking of the cookies (C1, C2 and C3, respectively), and its effects were evaluated on proximate, bioactive compounds, antioxidant, physical and inhibitory properties against a-amylase and a-glucosidase enzymes using standard methods. Also, sensory attributes of the cookies were determined using 9-point hedonic point.
\end{abstract}

Results: The results showed thickness were significantly $(p<0.05)$ reduced while diameter and spread ratio of the cookies increased as the level of MOLP increases. The inclusion of MOLP in the cookies led to significant $(p<0.05)$ enhancement in the bioactive compound, antioxidant and inhibitory properties of MOLP-substituted cookies. Also protein, ash, fat and fibre contents were significantly $(p<0.05)$ increased in MOLP-substituted cookies while carbohydrate and energy value reduced. The sensory evaluation revealed that MOLP-substituted cookies at the level of $2.5 \%$ were more acceptable than other MOLP-substituted cookies.

Conclusion: With the higher bioactive, antioxidant and inhibitory abilities against a-amylase and a-glucosidase enzymes and enhanced protein content of MOLP-substituted cookies, MOLP poses as a potential functional ingredient in baking of cookies.

Keywords: Antidiabetic, Antioxidant, Bioactive, Cookies, Sensory

\section{Background}

Moringa oleifera (MO) is a member of the family of Moringaceae. They are excellent sources of protein and contain very little fat and carbohydrates. Also, MO leaves are good sources of phytochemicals such as carotenoids, tocopherols and ascorbic acid with appreciable amount

\footnotetext{
*Correspondence: karigidikayode@yahoo.com

Department of Chemical Sciences, Biochemistry Unit, Olusegun Agagu University of Science and Technology, Okitipupa, Ondo State, Nigeria
}

of polyphenol and antioxidant ability (Saini et al. 2014). Moringa oleifera extracts have been reported to possessed different biological activities such as anti-inflammatory, antidiabetic, and antihyperlipidemic (Divya et al. 2019). Many studies have shown the potential use of different parts of MO in preparation of functional food such as stiff dough made from yam flour, biscuits, bread and cake (Páramo-Calderón et al. 2019; Oyeyinka and Oyeyinka 2018). Health concerns have increased the demand of consumers for functional foods, and this has 
prompted the food industry to tend towards functional food markets. Fortified functional foods have gained prominence as preventive agents against non-communicable diseases such as diabetes mellitus, hypertension and cardiovascular diseases (Shahzad et al. 2021). Cookies have become a prominent snack around the globe and are well consumed by people of all age groups because they are easily affordable, ready to eat, have long shelf life and can be obtained in different varieties (Baumgartner et al. 2018). Every year, intake of cookies reaches 10 million tonnes worldwide (Moro et al. 2018). It is noteworthy that most cookies like bread are made with sugar, refined wheat flour, and fat, which signifies that they are high calorie and low protein food (Mukkundur et al. 2017). Also, because of use of these recipes, health functionality and therapeutic values including antioxidative phytochemicals, minerals and protein are lacking (Kaur et al. 2019). Due to these, the need to produce functional cookies that will meet nutritional requirements and also provide health benefits is essential. Therefore, this study is aimed to investigate the effects of substitution of wheat flour with Moringa oleifera leaves powder (MOLP) on physical, nutritional, bioactive, antioxidant, and inhibitory properties against amylase and glucosidase enzymes of the Cookies.

\section{Methods}

Moringa oleifera leaves used in this study were collected in the premise of Olusegun Agagu University of science and technology (OAUSTECH), Okitipupa $\left(6^{\circ} 33^{\prime} \mathrm{N} 4^{\circ} 43^{\prime} \mathrm{E}\right)$, Ondo state, Nigeria. They were identified and authenticated at the Department of Biological sciences, OAUSTECH, Okitipupa. The voucher number (OAUSTECH/H/0241) was deposited in their herbarium. The leaves were washed with tap water to remove dirt. Thereafter, they were air-dried at ambient temperature for four weeks in the laboratory. The dried sample was milled using an electric blender and sieved (0.100 mm diameter) to obtain Moringa oleifera leaf powder (MOLP). Wheat flour and other ingredients (baking yeast, milk, fat, sugar and salt) for baking of the muffins were purchased from local supermarket in Okitipupa, Ondo state.

\section{Preparation of cookies}

Cookies were produced from wheat and wheat-Moringa oleifera composite flours using the modified procedure described by (Kaur et al. 2017).The Cookies formulation is shown in Table 1. Sugar, fat, eggs and milk were blended for 2 min using a three pin mixer. Thereafter, wheat flour, salt and baking powder were added and mixed for $20 \mathrm{~s}$. The dough was flattened into sheet and cut using cookies cutter. The cookies were baked at
Table 1 Recipe used for the preparation of Moringa oleifera supplemented cookies

\begin{tabular}{lllll}
\hline & C0 & C1 & C2 & C3 \\
\hline Wheat flour (g) & 130 & 126.75 & 123.5 & 117 \\
Moringa oleifera (g) & - & 3.25 & 6.5 & 13 \\
Sugar (g) & 35 & 35 & 35 & 35 \\
Butter (g) & 70 & 70 & 70 & 70 \\
Egg white (g) & 30 & 30 & 30 & 30 \\
Skimmed milk (g) & 8 & 8 & 8 & 8 \\
Salt (g) & 0.3 & 0.3 & 0.3 & 0.3 \\
Baking powder (g) & 0.4 & 0.4 & 0.4 & 0.4 \\
\hline
\end{tabular}

Values with different letter across the same row are significantly different $(p<$ 0.05)

$\mathrm{C} 0=$ Cookies made with $100 \%$ wheat flour; $\mathrm{C} 1=$ Cookies made with $97.5 \%$ wheat plus $2.5 \%$ Moringa oleifera flour; $\mathrm{C} 2=$ Cookies made with $95 \%$ wheat plus $5 \%$ Moringa oleifera flour; C3 = Cookies made with 90\% wheat plus 10\% Moringa oleifera flour

$200{ }^{\circ} \mathrm{C}$ for $25 \mathrm{~min}$ in a pre-heated oven. After baking, the cookies were allowed to stand at ambient temperature for $4 \mathrm{~h}$ and oven dried at $40{ }^{\circ} \mathrm{C}$ for $1 \mathrm{~h}$. Thereafter, they were milled and screened through a sieve $(0.100 \mathrm{~mm}$ diameter) to obtain cookies powder.

\section{Determination of functional properties}

Functional properties of the flours (Wheat, MOLP and composite flours) were assessed using bulk density (BD), swelling power (SWP), water absorption capacity (WAC) and oil absorption capacity (OAC).

\section{Determination of bulk density}

Bulk density was evaluated using the method of Maninder et al. (2007). Sample (1 g) was transferred into $10 \mathrm{~mL}$ graduated cylinder, and the cylinder was tapped until there was no further diminution of the sample level. The bulk density was calculated as the weight of sample per unit volume of sample $\left(\mathrm{g} / \mathrm{cm}^{3}\right)$.

Bulk density $=($ Weight of the sample/Volume of the sample).

\section{Determination of swelling power}

Swelling power was assayed using the method of Gani et al. (2013). Sample (1 g) of the sample was suspended in $10 \mathrm{~mL}$ distilled water and heated at $50{ }^{\circ} \mathrm{C}$ for $30 \mathrm{~min}$. Thereafter, the samples were cooled and centrifuged at $3000 \mathrm{~g}$ for $20 \mathrm{~min}$. Swelling power was calculated as follows: 
Swelling power $=$ Weight of swollen sample/Initial weight of dried sample.

\section{Determination of water absorption and oil absorption capacities}

Water absorption and Oil absorption capacities were assayed by the method of Bhat et al. (2016). Sample $(1.0 \mathrm{~g})$ was mixed with $10 \mathrm{~mL}$ distilled water or olive oil in a centrifuge tube and vortexed for $30 \mathrm{~min}$ at $25^{\circ} \mathrm{C}$. The slurry was then centrifuged at $5000 \mathrm{~g}$ for $15 \mathrm{~min}$, and the supernatant was decanted. The weight of the residue was measured. Water or oil absorption capacities were calculated as follows:

Water or oil absorption capacities $=(\mathrm{gGin}$ in weight/Original weight) $\times 100$.

\section{Determination of physical properties}

Physical properties of the cookies were evaluated using diameter, thickness and spread ratio (diameter/thickness). They were evaluated using the method of Hussain et al. (2006).

\section{Determination of proximate composition}

Proximate composition of cookies was assessed with the method of AOAC (2006). Moisture contents, crude fat, crude protein $(N \times 6.25)$, crude fibre and ash content were analysed using sub-components 925.09, 922.06, 960.52, 991.43 and 923.39, respectively. Carbohydrate was determined by difference in total percentage $\{100$-(moisture content + crude fat + crude protein + crude fibre + crude ash) $\}$, and energy value was evaluated using Atwater formula $=\{$ (Carbohydrate $\times 4)+($ Protein $\times 4)+($ Lipid $\times 9)\}$. Results were presented on dry weight basis.

\section{Preparation of extract}

The extract was prepared using the method of Kaur and Kaur (2018). Five gram (5 g) of the cookies was defatted with $50 \mathrm{~mL}$ of hexane, dried at ambient temperature for $24 \mathrm{~h}$. Thereafter, $1 \mathrm{~g}$ of the defatted cookies was extracted with $10 \mathrm{~mL}$ of methanol for $4 \mathrm{~h}$ at ambient temperature on test tube shaker. The slurry obtained was centrifuged at $5000 \times \mathrm{g}$ for $10 \mathrm{~min}$. The supernatant was used for determination of bioactive contents, antioxidant capacity and $\alpha$-amylase and $\alpha$-glucosidase enzymes inhibitions.

\section{Bioactive compounds}

Determination of total phenolic content (TPC)

Total phenolic contents of the cookies were determined using the method of Kim et al. (2003) as modified by Karigidi et al. (2018). Briefly $0.5 \mathrm{~mL}$ of the sample was mixed with $0.5 \mathrm{~mL}(10 \%)$ of Folin-Ciocalteu phenol reagent. After $5 \mathrm{~min}, 2.5 \mathrm{~mL}$ of $7 \% \mathrm{Na}_{2} \mathrm{CO}_{3}$ was added followed immediately with by addition of $2.5 \mathrm{~mL}$ of distilled water and shaken thoroughly. The mixture was kept in the dark for $90 \mathrm{~min}$ at room temperature. TPC was evaluated from Gallic acid standard curve and expressed as Gallic acid equivalent (mg GAE/100 g).

\section{Determination of total flavonoid content (TFC)}

The total flavonoid contents of the cookies were determined using the procedure described by Park et al. (2008). Briefly $0.3 \mathrm{~mL}$ of the sample was mixed with $3.4 \mathrm{~mL}(30 \%)$ of methanol, $0.15 \mathrm{~mL}(0.5 \mathrm{M})$ of $\mathrm{NaNO}_{2}$ and $0.15 \mathrm{~mL}(0.3 \mathrm{M})$ of $\mathrm{AlCl}_{3} 6 \mathrm{H}_{2} 0$ successively. After $5 \mathrm{~min}$, $1 \mathrm{~mL}$ of $1 \mathrm{M} \mathrm{NaOH}$ was added and mixed well. TFC was expressed as Quercetin equivalent (mg QUE/100 g).

\section{Antioxidant activity}

Total antioxidant capacity phosphomolybdate assay (TAC)

TAC of the cookies was determined using the method of (Prieto et al. 1999). Sample $(0.4 \mathrm{~mL})$ and $4.0 \mathrm{~mL}$ of phosphomolybdate reagent $(0.6 \mathrm{M}$ sulfuric acid, $28 \mathrm{mM}$ sodium phosphate and $4 \mathrm{mM}$ ammonium molybdate) was thoroughly mixed together. The mixture was capped and incubated in a boiling water bath at $95^{\circ} \mathrm{C}$ for $90 \mathrm{~min}$. The mixture was cooled to room temperature, and the absorbance of the cookies was measured at $695 \mathrm{~nm}$. The total antioxidant capacity was calculated from Ascorbic acid calibration curve and expressed as ascorbic acid equivalent (mg AAE/100 g).

\section{Determination of 2,2-diphenyl-1-picrylhydrazyl (DPPH) scavenging activity}

DPPH radical scavenging activity of the cookies was done using the method (Gyamfi et al. 1999). Briefly, $1.0 \mathrm{~mL}$ of sample was added to $4 \mathrm{~mL}$ of DPPH solution $(40 \mathrm{mg} / \mathrm{l})$ prepared in methanol. The cookies were mixed thoroughly and left in the dark for $30 \mathrm{~min}$. The absorbance was read at $520 \mathrm{~nm}$. The inhibition percentage was calculated.

Percentage inhibition of $\mathrm{DPPH}=\left\{\left(\begin{array}{ll}\mathrm{A}_{\mathrm{Crl}} & \left.-\mathrm{A}_{\mathrm{Sp}}\right)\end{array}\right)\right.$ $\left.\left(\mathrm{A}_{\mathrm{Cr}}\right)\right\} \times 100$.

where $\mathrm{A}_{\mathrm{Crl}}=$ absorbance of control and $\mathrm{A}_{\mathrm{Spl}}=$ absorbance of the sample. 


\section{Determination of Ferric reducing antioxidant potential (FRAP)}

FRAP of the cookies was done using the method of Benzie and strain (1996). The FRAP working reagent consisting of $25 \mathrm{~mL}$ acetate buffer, $2.5 \mathrm{~mL}$ TPTZ solution, and ferric chloride in ratio 10:1:1 was freshly prepared and warmed at $37{ }^{\circ} \mathrm{C}$ for 2 min before use. $0.2 \mathrm{~mL}$ of the sample and $2.80 \mathrm{~mL}$ of the FRAP reagent were added together and incubated for $30 \mathrm{~min}$ at room temperature. FRAP was evaluated from ferrous sulphate standard curve and expressed as $\left(\mathrm{mg} \mathrm{Fe}^{2+} \mathrm{E} / 100 \mathrm{~g}\right)$.

\section{Determination of reducing power (RP)}

$\mathrm{RP}$ of the cookies was done using the method of Oyaizu (1986). $1 \mathrm{~mL}$ of sample, $1 \mathrm{~mL}$ phosphate buffer $(0.2 \mathrm{M}$, $\mathrm{pH}$ 6.6) and $1 \mathrm{~mL}$ of potassium ferricyanide (1\%) were added together and incubated for $20 \mathrm{~min}$ at $50{ }^{\circ} \mathrm{C}$. The reaction was stopped by $1 \mathrm{~mL}$ trichloroacetic acid (10\%). $1.0 \mathrm{~mL}$ of the upper portion was taken, mixed with $1 \mathrm{~mL}$ of distilled water and followed by $1 \mathrm{~mL}$ ferric chloride $(0.1 \%)$. The absorbance was read at $700 \mathrm{~nm}$, and reducing power was determined from ascorbic acid calibration curve and expressed as ascorbic acid equivalent (mg $\mathrm{AAE} / 100 \mathrm{~g})$.

\section{Antidiabetic activity}

\section{Determination of amylase inhibition assay (Al)}

Amylase inhibition (AI) of the cookies was evaluated with the method of Worthington (1993). $500 \mu \mathrm{L}(0.1-0.4 \mathrm{mg} /$ $\mathrm{mL})$ of sample and $500 \mu \mathrm{L}(0.02 \mathrm{M})$ of sodium phosphate buffer (pH 6.9 with $0.006 \mathrm{M} \mathrm{NaCl}$ ) containing $0.5 \mathrm{mg} / \mathrm{mL}$ $\alpha$-amylase solution were mixed together and incubated at room temperature for $10 \mathrm{~min}$. Thereafter, $500 \mu \mathrm{L}(1 \%)$ of starch solution prepared with $0.02 \mathrm{M}$ sodium phosphate buffer (pH 6.9 with $0.006 \mathrm{M}$ sodium chloride) was added. The reaction mixture was then incubated at $25 \mathrm{oC}$ for $10 \mathrm{~min}$. The reaction was halted with $1.0 \mathrm{~mL}(96 \mathrm{mM})$ of dinitrosalicylic acid. The test tubes were then incubated in a boiling water bath for $5 \mathrm{~min}$ and allowed to cool. The absorbance was read at $540 \mathrm{~nm}$. The inhibition percentage was calculated.

Percentage inhibition of Amylase $=\left\{\left(\mathrm{A}_{\mathrm{Crl}}-\mathrm{A}_{\mathrm{Spl}}\right) /\right.$ $\left.\left(\mathrm{A}_{\mathrm{Cr}}\right)\right\} \times 100$.

where $\mathrm{A}_{\mathrm{Crl}}=$ absorbance of control and $\mathrm{A}_{\mathrm{Spl}}=$ absorbance of the sample.

\section{Determination of glucosidase inhibition assay (GI)}

Glucosidase inhibition (GI) of the cookies was evaluated with the method of Apostolidis et al. (2007). GI of the samples was done using the method of Apostolidis et al. (2007). $500 \mu \mathrm{L}(0.1-0.4 \mathrm{mg} / \mathrm{mL})$ of sample was added to $1000 \mu \mathrm{l} \alpha$-glucosidase solution (1.0 U/L) prepared in of
$0.1 \mathrm{M}$ phosphate buffer $(\mathrm{pH}$ 6.9) and pre-incubated for $10 \mathrm{~min}$ at $25^{\circ} \mathrm{C}$. After pre-incubation, $500 \mu \mathrm{L}$ of $5 \mathrm{mM}$ nitrophenyl-glucopyranoside solution prepared in $0.1 \mathrm{M}$ phosphate buffer ( $\mathrm{pH}$ 6.9) was added. $\mu$ The reaction mixture was incubated at $25^{\circ} \mathrm{C}$ for $5 \mathrm{~min}$. The absorbance of the reaction mixture was measured at $405 \mathrm{~nm}$. The percentage inhibition was calculated.

Percentage inhibition of Glucosidase $=\left\{\left(\mathrm{A}_{\mathrm{Crl}}-\mathrm{A}_{\mathrm{Spl}}\right) /\right.$ $\left.\left(\mathrm{A}_{\mathrm{Cr}}\right)\right\} \times 100$.

where $\mathrm{A}_{\mathrm{Crl}}=$ absorbance of control and $\mathrm{A}_{\mathrm{Spl}}=$ absorbance of the sample.

\section{Sensory evaluation}

Sensory evaluation of cookies was done by a trained consumer panel $(n=15) ; 9$ females and 6 male which were staff (4) and students (11) of School of Science, OAUSTECH according to the method described by Seczyk et al. (2016). Before evaluation of the cookies, panellists were asked for any allergies to wheat flour, Moringa oleifera and cookies. Cookies were screened for colour, flavour, texture, taste, and overall quality using a ninepoint hedonic scale ranging from extremely unpleasant to extremely pleasant.

\section{Statistical analysis}

Data were expressed as the mean $\pm \mathrm{SD}$ of three measurements, analysed by ANOVA, and the means separated by least significant difference $(p<0.05)$, using SPSS Version 20. Pearson correlation was calculated to determine the relationship between polyphenol content, antioxidant and enzymes inhibitions activities. Significant was established at $p<0.05$. $\mathrm{IC}_{50}$ was evaluated from the graph.

\section{Results}

Bioactive, antioxidant and functional characteristics of wheat, Moringa oleifera and wheat-Moringa oleifera composite flours used in the preparation of cookies

The result of bioactive, antioxidant and functional properties of wheat, Moringa oleifera and composite flours used in baking the cookies is presented in Table 2. Moringa oleifera powder $(\mathrm{MOLP})$ has significant $(p<0.05)$ higher bioactive and antioxidant properties than the wheat flour. There was significant $(p<0.05)$ increase in the bioactive and antioxidant properties of composite flour as the level of MOLP increases in the composite flours. Also, the bulk density of wheat flour was significantly $(p<0.05)$ higher than MOLP while swelling power, water and oil absorption capacities of wheat flower were significantly $(p<0.05)$ lower than MOLP. 
Table 2 Bioactive, antioxidant and functional characteristics of wheat, Moringa oleifera and wheat-Moringa oleifera composite flours used in preparation of cookies

\begin{tabular}{|c|c|c|c|c|c|}
\hline & F100 & $\mathrm{F} 2.5 \mathrm{M}$ & F5M & F10M & M100 \\
\hline TPC & $37.53 \pm 4.08^{e}$ & $51.09 \pm 2.53^{d}$ & $58.20 \pm 2.13^{c}$ & $70.12 \pm 1.64^{b}$ & $100.21 \pm 1.61^{\mathrm{a}}$ \\
\hline TFC & $21.20 \pm 1.04^{\mathrm{e}}$ & $28.15 \pm 0.56^{d}$ & $31.93 \pm 0.48^{c}$ & $33.64 \pm 0.91^{b}$ & $85.27 \pm 3.34^{\mathrm{a}}$ \\
\hline TAC & $22.15 \pm 1.18^{d}$ & $34.32 \pm 0.48^{c}$ & $33.24 \pm 2.92^{c}$ & $41.14 \pm 1.71^{b}$ & $115.88 \pm 12.32^{2}$ \\
\hline $\mathrm{RP}$ & $12.63 \pm 0.10^{e}$ & $16.95 \pm 0.47^{d}$ & $18.97 \pm 0.28^{c}$ & $28.81 \pm 1.31^{b}$ & $55.04 \pm 0.27^{\mathrm{a}}$ \\
\hline DPPH & $33.41 \pm 2.81^{\mathrm{a}}$ & $42.71 \pm 1.71^{c}$ & $53.65 \pm 1.74^{b}$ & $55.51 \pm 3.20^{b}$ & $80.96 \pm 2.86^{\mathrm{a}}$ \\
\hline ABTS & $36.43 \pm 0.78^{e}$ & $41.19 \pm 1.16^{\mathrm{d}}$ & $44.49 \pm 0.22^{c}$ & $47.88 \pm 0.11^{b}$ & $50.98 \pm 0.48^{\mathrm{a}}$ \\
\hline $\mathrm{BD}$ & $0.80 \pm 0.01^{\mathrm{a}}$ & $0.78 \pm 0.02^{\mathrm{a}}$ & $0.74 \pm 0.01^{b}$ & $0.66 \pm 0.03^{c}$ & $0.43 \pm 0.02^{d}$ \\
\hline SWP & $3.07 \pm 0.21^{b}$ & $2.73 \pm 0.08^{b}$ & $2.97 \pm 0.15^{b}$ & $2.84 \pm 0.11^{b}$ & $6.15 \pm 0.57^{a}$ \\
\hline WAC & $2.13 \pm 0.06^{b}$ & $1.27 \pm 0.10^{c}$ & $1.07 \pm 0.11^{c}$ & $1.12 \pm 0.10^{c}$ & $3.91 \pm 0.50^{\mathrm{a}}$ \\
\hline OAC & $0.80 \pm 0.11^{b}$ & $0.82 \pm 0.09^{b}$ & $0.90 \pm 0.09^{b}$ & $1.05 \pm 0.14^{b}$ & $1.95 \pm 0.19^{\mathrm{a}}$ \\
\hline
\end{tabular}

Values with different letter across the same row are significantly different $(p<0.05)$

$\mathrm{F} 100=$ wheat flour, $\mathrm{F} 2.5 \mathrm{M}=97.5 \%$ wheat flour $+2.5 \%$ Moringa oleifera flour; $\mathrm{F} 5 \mathrm{M}=95 \%$ wheat flour $+5 \%$ Moringa oleifera flour; $\mathrm{F} 10 \mathrm{M}=90 \%$ wheat flour $+10 \%$ Moringa oleifera flour; $\mathrm{M} 100=$ Moringa oleifera flour

TPC, total phenolics content (mg GAE/100 g); TFC, total flavonoid (mg QUE/100 g); TAC, total antioxidant capacity (mg AAE/100 g); RP, reducing power (mg AAE/100 g); DPPH, 2,2-Diphenyl-1-picrylhydrazyl scavenging activity (\% inhibition); ABTS, 2, 2-azobis-3-ethylbenzothiazoline-6-sulfonate radical scavenging ability (\% inhibition); $\mathrm{BD}$, bulk density $\left(\mathrm{g} / \mathrm{cm}^{3}\right)$; SWP, swelling power $(\mathrm{g} / \mathrm{g})$; WAC, water absorption capacity (\%); OAC, oil absorption (\%)

Table 3 Nutritional (dry weight basis) and physical properties of Moringa oleifera supplemented cookies

\begin{tabular}{|c|c|c|c|c|}
\hline & $\mathrm{CO}$ & $\mathrm{C} 1$ & $\mathrm{C} 2$ & C3 \\
\hline Protein (\%) & $10.56 \pm 0.15^{c}$ & $12.20 \pm 0.09^{b}$ & $12.49 \pm 0.20^{b}$ & $15.30 \pm 0.18^{a}$ \\
\hline Ash (\%) & $3.12 \pm 0.18^{c}$ & $3.28 \pm 0.08^{c}$ & $4.20 \pm 0.05^{b}$ & $7.98 \pm 0.06^{\mathrm{a}}$ \\
\hline Fat (\%) & $14.21 \pm 0.30^{c}$ & $14.92 \pm 0.18^{b}$ & $15.10 \pm 0.10^{b}$ & $15.50 \pm 0.10^{\mathrm{a}}$ \\
\hline Fibre (\%) & $2.50 \pm 0.05^{b}$ & $2.42 \pm 0.03^{b}$ & $2.45 \pm 0.09^{b}$ & $2.67 \pm 0.03^{a}$ \\
\hline Moisture (\%) & $7.75 \pm 0.26^{\mathrm{a}}$ & $7.92 \pm 0.10^{\mathrm{a}}$ & $7.93 \pm 0.28^{\mathrm{a}}$ & $7.42 \pm 0.08^{b}$ \\
\hline $\mathrm{CHO}(\%)$ & $61.86 \pm 0.36^{\mathrm{a}}$ & $59.27 \pm 0.31^{b}$ & $57.83 \pm 0.20^{b}$ & $51.14 \pm 0.16^{c}$ \\
\hline Energy value (KJ/100 g) & $417.58 \pm 1.95^{b}$ & $420.12 \pm 0.70^{\mathrm{a}}$ & $417.17 \pm 0.96^{b}$ & $405.26 \pm 1.02^{c}$ \\
\hline Thickness $(\mathrm{cm})$ & $0.90 \pm 0.03^{\mathrm{a}}$ & $0.86 \pm 0.05^{\mathrm{a}}$ & $0.75 \pm 0.03^{b}$ & $0.75 \pm 0.02^{b}$ \\
\hline Diameter (cm) & $4.98 \pm 0.10^{b}$ & $5.35 \pm 0.24^{c}$ & $5.68 \pm 0.19^{\mathrm{a}}$ & $5.35 \pm 0.06^{b}$ \\
\hline Spread ratio & $5.50 \pm 0.20^{c}$ & $6.21 \pm 0.20^{b}$ & $7.55 \pm 0.57^{\mathrm{a}}$ & $7.08 \pm 0.46^{\mathrm{a}}$ \\
\hline
\end{tabular}

Values were presented as Mean \pm SD

Values with different letter across the same row are significantly different $(p<0.05)$

$\mathrm{C} 0=$ cookies made with $100 \%$ wheat flour; $\mathrm{C} 1=$ cookies made with $97.5 \%$ wheat plus $2.5 \%$ Moringa oleifera flour; $\mathrm{C} 2=$ cookies made with $95 \%$ wheat plus $5 \%$ Moringa oleifera flour; $\mathrm{C} 3=$ cookies made with $90 \%$ wheat plus $10 \%$ Moringa oleifera flour; $\mathrm{CHO}$, carbohydrate (nitrogen free extract)

Table 4 Bioactive and antioxidant properties of Moringa oleifera supplemented cookies

\begin{tabular}{lllll}
\hline & C0 & C1 & C2 & C3 \\
\hline TPC (mg GAE/100 g) & $19.39 \pm 0.43^{d}$ & $30.17 \pm 0.43^{c}$ & $37.53 \pm 0.18^{\mathrm{b}}$ & $41.34 \pm 0.40^{\mathrm{a}}$ \\
TFC(mg QUE/100 g) & $12.42 \pm 1.93^{\mathrm{d}}$ & $24.58 \pm 2.09^{\mathrm{c}}$ & $29.91 \pm 3.24^{\mathrm{b}}$ & $32.69 \pm 1.06^{\mathrm{a}}$ \\
TAC(mg AAE/100 g) & $13.54 \pm 0.63^{\mathrm{b}}$ & $15.04 \pm 1.49^{\mathrm{b}}$ & $17.62 \pm 0.57^{\mathrm{a}}$ & $18.76 \pm 0.65^{\mathrm{a}}$ \\
DPPH (\% inhibition) & $31.19 \pm 3.72^{\mathrm{c}}$ & $38.15 \pm 1.17^{\mathrm{b}}$ & $40.42 \pm 1.28^{\mathrm{b}}$ & $47.23 \pm 0.81^{\mathrm{a}}$ \\
FRAP(mg Fe+E/100 g) & $21.48 \pm 1.56^{\mathrm{b}}$ & $22.70 \pm 0.15^{\mathrm{b}}$ & $29.10 \pm 0.98^{\mathrm{a}}$ & $31.48 \pm 2.05^{\mathrm{a}}$ \\
RP(mg AAE/100 g) & $18.48 \pm 0.69^{\mathrm{d}}$ & $20.63 \pm 0.93^{\mathrm{c}}$ & $22.22 \pm 0.51^{\mathrm{b}}$ & $27.23 \pm 2.17^{\mathrm{a}}$ \\
\hline
\end{tabular}

Values were presented as Mean \pm SD

Values with different letter across the same row are significantly different $(p<0.05)$

$\mathrm{C} 0=$ cookies made with $100 \%$ wheat flour; $\mathrm{C} 1=$ cookies made with $97.5 \%$ wheat plus $2.5 \%$ Moringa oleifera flour; $\mathrm{C} 2=$ cookies made with $95 \%$ wheat plus $5 \%$ Moringa oleifera flour; $\mathrm{C} 3=$ cookies made with $90 \%$ wheat plus $10 \%$ Moringa oleifera flour 


\section{Nutritional and physical properties of cookies}

The result of proximate composition of cookies fortified with MOLP is presented in Table 3. The result showed that there was a significant $(p<0.05)$ increase in the protein (10.56-15.30 g/100 g), ash (3.12-7.98 g/100 g) and fat (14.21-15.50 g/100 g) contents of Moringa oleifera fortified cookies which were proportional to level of MOLP addition in the cookies. Also, the result of physical characteristics of Moringa oleifera fortified cookies is presented in Table 3 . There was a significant $(p<0.05)$ increase in the diameter and spread ratio in the fortified cookies as the level of Moringa oleifera increased. There was significant $(p<0.05)$ decrease in the thickness of Moringa oleifera fortified cookies but the difference was not significant $(p<0.05)$ at the level of $2.5 \%$.

\section{Bioactive component and antioxidant properties of cookies}

The result of bioactive and antioxidant properties of Moringa oleifera fortified cookies is presented in Table 4. The result showed that the bioactive component; total phenolics (19.39-41.34 mg GAE/100 g) and total flavonoids (12.42-32.69 mg QUE/100 g)), total antioxidant capacity

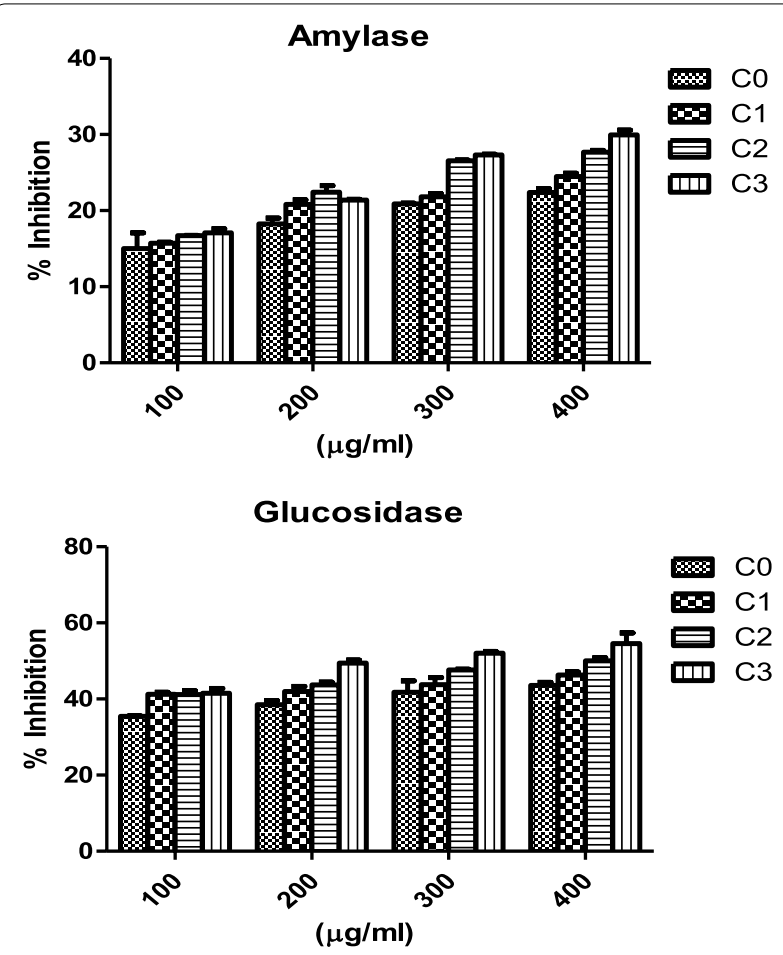

Fig. 1 a-amylase and a-glucosidase inhibitory properties of Moringa oleifera supplemented cookies. C0 = Cookies made with $100 \%$ wheat flour; $\mathrm{C} 1=$ Cookies made with $97.5 \%$ wheat plus $2.5 \%$ Moringa oleifera flour; C2 = Cookies made with 95\% wheat plus 5\% Moringa oleifera flour; C3 = Cookies made with $90 \%$ wheat plus $10 \%$ Moringa oleifera flour
Table $5 \quad \mathrm{IC}_{50}(\mu \mathrm{g} / \mathrm{ml})$ of Moringa oleifera supplemented cookies against a-amylase and a-glucosidase enzymes

\begin{tabular}{lllll}
\hline & C0 & C1 & C2 & C3 \\
\hline a-Amylase & $1020.50 \pm 6.50^{\mathrm{a}}$ & $975.80 \pm 5.82^{\mathrm{b}}$ & $912.40 \pm 8.50^{\mathrm{c}}$ & $850.50 \pm 4.63^{\mathrm{d}}$ \\
a-Glucosidase & $460.82 \pm 3.20^{\mathrm{a}}$ & $432.50 \pm 3.90^{\mathrm{b}}$ & $400.25 \pm 5.40^{\mathrm{c}}$ & $381.60 \pm 3.85^{\mathrm{d}}$ \\
\hline
\end{tabular}

Values were presented as Mean \pm SD

Values with different letter across the same row are significantly different $(p<$ $0.05)$

$\mathrm{CO}=$ cookies made with $100 \%$ wheat flour; $\mathrm{C} 1=$ cookies made with $97.5 \%$ wheat plus 2.5\% Moringa oleifera flour; C2 = cookies made with $95 \%$ wheat plus $5 \%$ Moringa oleifera flour; $\mathrm{C} 3=$ cookies made with $90 \%$ wheat plus $10 \%$ Moringa oleifera flour

(13.54-18.76 mg AAE/100 g), DPPH scavenging activities (31.19-47.23\% inhibition), ferric reducing antioxidant property (21.48-31.48 $\left.\mathrm{mg} \mathrm{Fe}{ }^{2+} \mathrm{E} / 100 \mathrm{~g}\right)$ and reducing power (18.48-27.23 mg AAE/100 g) of the Moringa oleifera fortified cookies increased significantly $(p<0.05)$ as the level of Moringa oleifera is increased in the cookies.

\section{Antidiabetic: $a$-amylase and a-glucosidase enzymes inhibition properties of cookies}

The result of inhibitory properties of Moringa oleifera fortified cookies against $\alpha$-amylase and $\alpha$-glucosidase enzymes is presented in Fig. 1 and the $\mathrm{IC}_{50}$ presented in Table 5.The result showed that there was significant $(p<0.05)$ increase in the ability of MOLP fortified cookies to inhibit $\alpha$-amylase and $\alpha$-glucosidase enzymes as the level of MOLP were increased in the cookies. Cookies fortified at the level of 10\% Moringa oleifera had the lowest $\mathrm{IC}_{50}(850.50 \mu \mathrm{g} / \mathrm{mL}, 381.60 \mu \mathrm{g} / \mathrm{mL})$ against $\alpha$-amylase and $\alpha$-glucosidase, respectively.

\section{Correlation analysis}

The Pearson correlation analysis (Table 6) showed that there was significant $(p<0.05)$ positive correlation among the bioactive contents, antioxidant activities and inhibition capacity against $\alpha$-amylase and $\alpha$-glucosidase enzymes. The correlation between phenolics and $\alpha$-amylase and $\alpha$-glucosidase enzymes are 0.90 and 0.87 , respectively, while between flavonoid and $\alpha$-amylase and $\alpha$-glucosidase enzymes are 0.95 and 0.95 , respectively.

\section{Sensory attributes of cookies}

The result of sensory evaluation of the fortified cookies is presented in Table 7 . There was significant $(p<0.05)$ decrease in the consumer's acceptance of the cookies as the level of MOLP increased in the fortified cookies. Colour ranged from 8.57 to 4.57 , flavour ranged from 8.29 to 5.14 , taste ranged from 8.43 to 5.57 , texture ranged from 8.29 to 5.43 and overall quality ranged from 8.29 to 4.86 . There are no significant differences $(p<0.05)$ in 
Table 6 Correlations among bioactive compounds, antioxidant activities and enzyme inhibitions

\begin{tabular}{lllllllll}
\hline & TPC & TFC & TAC & RP & FRAP & DPPH & AMY & GLU \\
\hline TPC & 1 & 0.76 & 0.85 & 0.93 & 0.90 & 0.87 & 0.90 & 0.87 \\
TFC & 0.76 & 1 & 0.90 & 0.81 & 0.85 & 0.90 & 0.95 & 0.95 \\
TAC & 0.85 & 0.90 & 1 & 0.77 & 0.91 & 0.81 & 0.92 & 0.91 \\
RP & 0.93 & 0.81 & 0.77 & 1 & 0.86 & 0.89 & 0.91 & 0.88 \\
FRAP & 0.90 & 0.85 & 0.91 & 0.86 & 1 & 0.80 & 0.95 \\
DPPH & 0.87 & 0.90 & 0.81 & 0.89 & 0.80 & 1 & 0.91 \\
AMY & 0.90 & 0.95 & 0.92 & 0.91 & 0.95 & 0.92 & 0.92 \\
GLU & 0.87 & 0.95 & 0.91 & 0.88 & 0.91 & 0.92 & 0.97 \\
\hline
\end{tabular}

TPC, Total phenolics; TFC, total flavonoid; TAC, total antioxidant capacity; DPPH, 2,2 diphenyl-1-picrylhydrazyl scavenging activity; RP, reducing power; FRAP, ferric reducing antioxidant potential; $A M Y$, amylase inhibition, glucosidase inhibition

Table 7 Sensory attributes of Moringa oleifera supplemented cookies

\begin{tabular}{lllll}
\hline & C0 & C1 & C2 & C3 \\
\hline Colour & $8.57 \pm 0.53^{\mathrm{a}}$ & $7.71 \pm 0.49^{\mathrm{a}}$ & $5.86 \pm 0.69^{\mathrm{b}}$ & $4.57 \pm 0.79^{\mathrm{c}}$ \\
Flavour & $8.29 \pm 0.49^{\mathrm{a}}$ & $7.71 \pm 0.45^{\mathrm{a}}$ & $6.43 \pm 0.53^{\mathrm{b}}$ & $5.14 \pm 0.90^{\mathrm{c}}$ \\
Taste & $8.43 \pm 0.53^{\mathrm{a}}$ & $8.00 \pm 0.58^{\mathrm{a}}$ & $6.71 \pm 0.95^{\mathrm{b}}$ & $5.57 \pm 0.98^{\mathrm{c}}$ \\
Texture & $8.29 \pm 0.50^{\mathrm{a}}$ & $7.29 \pm 0.26^{\mathrm{a}}$ & $6.43 \pm 0.79^{\mathrm{b}}$ & $5.43 \pm 0.79^{\mathrm{c}}$ \\
Overall quality & $8.29 \pm 0.76^{\mathrm{a}}$ & $7.43 \pm 0.53^{\mathrm{a}}$ & $6.43 \pm 0.51^{\mathrm{b}}$ & $4.86 \pm 0.90^{\mathrm{c}}$
\end{tabular}

Values were presented as Mean \pm SD

Values with different letter across the same row are significantly different $(p<$ $0.05)$

$\mathrm{CO}=$ cookies made with $100 \%$ wheat flour; $\mathrm{C} 1=$ cookies made with $97.5 \%$ wheat plus $2.5 \%$ Moringa oleifera flour; $\mathrm{C} 2=$ cookies made with $95 \%$ wheat plus $5 \%$ Moringa oleifera flour; C3 = cookies made with $90 \%$ wheat plus $10 \%$ Moringa oleifera flour

parameter of cookies made with wheat flour and those fortified with $2.5 \%$ MOLP.

\section{Discussion}

The present study evaluated the effects of substitution of wheat flour with MOLP on the physical, nutritional, bioactive, antioxidant and antidiabetic properties of cookies. As shown in Table 2, the improved bioactive and antioxidant properties of the composite flours and MOLP over wheat flour is a likely evidence that inclusion of MOLP might produce cookies with enhanced bioactive and antioxidant characteristics. The result showed agreement with the work of Nakov et al. (2020) that wheat flour exhibited relatively lower antioxidant property relative to apple peel powder which is a natural botanical.

Moisture content is an index of shelf life of food as high moisture content enhances microbial growth while fibre popularly known as non-starchy polysaccharides has become prominent component of food because of its numerous health functions (Karigidi and Olaiya 2021). However, there were no significant $(p<0.05)$ changes in the fibre and moisture contents of the fortified cookies but the carbohydrates and energy values of the fortified cookies were significant decreased upon fortification with MOLP. Dietary proteins are essential for growth and repair of worn-out tissues. The protein enhancement upon fortification with MOLP might be due to the vast protein contents found in Moringa oleifera leaves (Su and Chen 2020). The enhanced protein content of cookies might be utilized for school children in area where protein deficiency is predominant. This study agrees with the research of Asadi and Khan (2020), where he reported that Beetroot leaves powder enhanced the protein content of wheat cookies.

Total phenolics and flavonoids are important bioactive compounds with antioxidant functions in food (Smuda et al. 2018). Their increment in this study corroborated many studies where natural botanical has been used to enhance the bioactive component of wheat cookies (Kaur et al 2019, 2017). Antioxidants are chemical entities that prevent oxidation by free radicals in the cell, thereby preventing chronic diseases (Karigidi et al 2019). The enhanced bioactive and antioxidant properties of the Moringa oleifera fortified cookies are in agreement with the study of Nakov et al (2020), where addition of apple powder increased the antioxidant activity of wheat cookies. The fortified cookies might be used to prevent freeradical related diseases.

The antidiabetic ability of the fortified cookies was assessed by their ability to inhibit prominent hydrolysing enzymes which have been implicated in treatment and management of diabetes mellitus. These enzymes catalyse the breakdown of large carbohydrate molecules into smaller absorbable units in the body, and their excessive activity has been reported in diabetes mellitus. In lieu of this, their inhibition has become a treatment target in diabetes mellitus (Gajera et al. 2017). The decrease in $\mathrm{IC}_{50}$ upon addition of MOLP in the cookies might be attributed to enhance bioactive compound of the cookies as many studies have reported the ability of phenolics 
and flavonoids to inhibit these enzymes (Apostolidis and Lee 2010; Taslimi and Gulcin 2017). The results of correlation analysis attested to the fact that the increase in bioactive compounds might be responsible for the enhanced antioxidant and inhibitory properties against $\alpha$-amylase and $\alpha$-glucosidase enzymes.

As shown in Table 7, there was decrease in consumers' acceptance of the cookies. The reason for this might be that inclusion of MOLP has given the cookies a bitter taste and smell, which has caused a decrease in taste, flavour, colour and overall quality as many research have reported the bitter taste of MOLP (Gopalakrishman et al. 2016; Nambiar and Parnami 2008). The results obtained for cookies fortified with MOLP are similar to the one reported by Babiker et al. (2020) where inclusion of Carob flour led to decrease in sensory attributes of cookies.

\section{Conclusions}

Partial substitution of wheat flour with MOLP in cookies improved the protein, fat and ash contents. Also, there was enhanced bioactive, antioxidant and inhibitory properties against $\alpha$-amylase and $\alpha$-glucosidase enzymes of the supplemented cookies. Cookies with $2.5 \%$ MOLP had the best score according to the sensory panellists. Due to its sensory scores, cookies fortified at level of 2.5\% MOLP are recommended for people especially, diabetic and pre-diabetic patients.

\section{Abbreviations \\ Al: Amylase inhibition; BD: Bulk density; DPPH: 2,2-Diphenyl-1-picrylhydrazyl; FRAP: Ferric reducing antioxidant power; Gl: Glucosidase inhibition; MO: Mor- inga oleifera; MOLP: Moringa oleifera Leaf power; OAC: Oil absorption capacity; RP: Reducing power; SWP: Swelling power; TAC: Total antioxidant capacity; WAC: Water absorption.}

\section{Acknowledgements}

None.

\section{Authors' contributions}

The study was carried in collaboration among all authors. Authors KOK and APF designed the work; Authors KOK, APF, ESA, TO and FOA carried out all laboratory works, performed statistical analysis and wrote the manuscript. All authors read and approved the final manuscript.

\section{Funding}

No funding was received for this study.

\section{Availability of data and materials}

Available on request.

\section{Declarations}

Ethics approval and consent to participate

Not applicable.

\section{Consent for publication}

Not applicable.

\section{Competing interests}

The authors declare no competing financial interests.

Received: 13 January 2022 Accepted: 22 February 2022

Published online: 04 March 2022

\section{References}

Apostolidis E, Lee CM (2010) In vitro potential of Ascophyllum nodosum phenolic antioxidant-mediated alpha-glucosidase and alpha-amylase inhibition. J Food Sci 75:H97-H102

Apostolidis E, Kwon YI, Shetty K (2007) Inhibitory potential of herb, fruit and fungal enriched cheese against key enzymes linked to type-2 diabetes and hypertension. Innov Food Sci Emerg Technol 8:46-54

Asadi SZ, Khan MA (2020) The effect of beetroot (Beta vulgaris L.) leaves powder on nutritional, textural, sensorial and antioxidant properties of cookies. J Culinary Sci Technol. https://doi.org/10.1080/15428052.2020. 1787285

Association of Official Analytical Chemists (AOAC) (2006) Official methods of analysis, Washington, DC, USA

Babiker EE, Özcan MM, Ghafoor K, Al-Juhaimi F, Ahmed IAM, Almusallam IA (2020) Physico-chemical and bioactive properties, fatty acids, phenolic compounds, mineral contents, and sensory properties of cookies enriched with carob flour. J Food Process Preserv 44(10):e14745

Baumgartner B, Özkaya B, Saka I, Özkaya H (2018) Functional and physical properties of cookies enriched with dephytinized oat bran. J Cereal Sci 80:24-30

Benzie F, Strain JJ (1996) The ferric reducing ability of plasma (FRAP) as a measure of "antioxidant power": the FRAP assay. Anal Biochem 239:70-76

Bhat NA, Wani IA, Hamdani AM, Gani A, Masoodi FA (2016) Physicochemical properties of whole wheat flour as affected by gamma irradiation. LWT Food Sci Technol. https://doi.org/10.1016/j.lwt.2016.03.024

Divya KG, Rubeena M, Andalil R, Erni B, Sundaramoorthy B, Thatipelli S, Koppala N, Sunil Kumar KNS, Shakila R (2019) Identity profile of Moringa oleifera Lam. Flower Int J Bot Stud 4(4):90-99

Gajera HP, Gevariya SN, Hirpara DG, Patel SV, Golakiya BA (2017) Antidiabetic and antioxidant functionality associated with phenolic constituents from fruits parts of indigenous black Jamun (Syzygium cumini L.) landraces. J Food Sci Technol. https://doi.org/10.1007/s13197-017-2756-8

Gani A, Wani SM, Masoodi FA, Salim R (2013) Characterization of rice starches extracted from Indian cultivars. Food Sci Technol Int 19:143. https://doi. org/10.1177/1082013212442189

Gopalakrisnan L, Doriya K, Kumar DS (2016) Moringa oleifera: a review on nutritive importance and its medicinal application. Food Sci Hum Welln 5:49-56

Gyamfi M, Yonamine M, Aniya Y (1999) Free radical scavenging action of medicinal herbs from Ghana: Thonningia sanguine on experimentally induced liver injuries. Gen Pharmacol 32(6):661-667

Hussain S, Anjum F, Butt M, Khan M, Asghar A (2006) Physical and sensory attributes of flaxseed flour supplemented cookies. Turk J Biol 30:87-92

Karigidi KO, Olaiya CO (2021) Improving the nutritional quality of Yam flour by substitution with Curculigo pilosa and in vitro digestibility and sensory analysis of its pasta. Food Meas. https://doi.org/10.1007/ s11694-021-01114-2

Karigidi KO, Ojebode ME, Olaiya CO (2018) Effect of cooking on antioxidant and enzymes activity linked to carbohydrate metabolism and lipid peroxidation of eggplant (Solanum melongena). Pertanika J Trop Agric Sci 41(4):1717-1730

Karigidi KO, Ojebode ME, Anjorin OJ, Omiyale BO, Olaiya CO (2019) Antioxidant activities of methanol extracts of Curculigo pilosa rhizome and Gladilous psittascinus corm against lipid peroxidation in rat's liver and heart. J Herbs Spices Med Plants 25(1):1-10

Kaur R, Kaur M (2018) Microstructural, physicochemical, antioxidant, textural and quality characteristics of wheat muffins as influenced by partial replacement with ground Flaxseed. LWT Food Sci Technol 91:278-285

Kaur M, Singh V, Kaur R (2017) Effect of partial replacement of wheat flour with varying levels of flaxseed flour on physicochemical, antioxidant and sensory characteristics of cookies. Bioact Carbohydr Diet Fibre 9:14-20 
Kaur P, Sharma P, Kumar V, Panghal A, Gat KJ, Y, (2019) Effect of addition of Flaxseed flour on phytochemical, physicochemical, nutritional, and textural properties of cookies. J Saudi Soc Agric Sci 18:372-377

Kim DO, Jeong SW, Lee CY (2003) Antioxidant capacity of phenolic phytochemicals from various cultivars of Plums. Food Chem 81:321-326

Maninder K, Kawaljit SS, Narpinder S (2007) Comparative study of functional, thermal and pasting properties of flours from different field Pea and Pigeon Pea cultivars. Food Chem 104:259-267

Moro TMA, Celegatti CM, Pereira APA, Lopes AS, Barbin DF, Pastore GM, Clerici MTPS (2018) Use of Burdock root flour as a prebiotic ingredient in cookies. LWT Food Sci Technol 90:540-546

Mukkundur VA, Chaturvedi A, Kulathooran R et al (2017) Effect of green coffee extract on rheological, physico-sensory and antioxidant properties of bread. J Food Sci Technol 54:1827-1836

Nakov G et al (2020) Influence of Apple peel powder addition on the physicochemical characteristics and nutritional quality of bread wheat cookies. Food Sci Technol Int 26:574-582

Nambiar VS, Parnami S (2008) Standardization and organoleptic evaluation of drumstick (Moringa oleifera) leaves incorporated into traditional Indian recipes. Trees 3:1-7

Oyaizu M (1986) Studies on products of browning reactions: antioxidative activities of products of browning reaction prepared from glucosamine. Jpn J Nutr Diet 44:307-315

Oyeyinka AT, Oyeyinka SA (2018) Moringa oleifera as a food fortificant: recent trends and prospects. J Saudi Soc Agric Sci 17:127-136

Páramo-Calderón DE, Aparicio-Saguilán A, Aguirre-Cruz A, Carrillo-Ahumada J, Hernández-Uribe JP, Acevedo-Tello S, Torruco-Uco JG (2019) Tortilla added with Moringa oleifera flour: physicochemical, texture properties and antioxidant capacity. LWT Food Sci Technol 100:409-415

Park Y-S, Jung S-T, Kang S-G, Heo BK, Arancibia-Avila P, Toledo F, Gorinstein S (2008) Antioxidants and proteins in ethylene-treated kiwifruits. Food Chem 107:640-648

Prieto P, Pineda M, Aguilar M (1999) Spectrophotometric quantitation of antioxidant capacity through the formation of a phosphomolybdenum complex: specific application to the determination of vitamin E. Anal Biochem 26(9):337-341

Saini R, Prashanth KH, Shetty N, Giridhar P (2014) Elicitors, SA and MJ enhance carotenoids and tocopherol biosynthesis and expression of antioxidant related genes in Moringa oleifera Lam.leaves. Acta Physiol Plantarum 36:2695-2704

SeczykŁ, Swieca M, Gawlik-Dziki U (2016) Effect of carob (Ceratonia siliqua L.) flour on the antioxidant potential, nutritional quality, and sensory characteristics of fortified durum Wheat pasta. Food Chem 194:637-642

Shahzad MA, Ahmad N, Ismail T et al (2021) Nutritional composition and quality characterization of Lotus (Nelumbo nucifera Gaertn.) seed flour supplemented cookies. Food Meas 15:181-188

Smuda SS, Mohsen SM, Olsen K, Aly MH (2018) Bioactive compounds and antioxidant activities of some cereal milling byproducts. J Food Sci Technol 55:1134-1142

Su B, Chen X (2020) Current status and potential of Moringa oleifera leaf as an alternative protein source for animal feeds. Front Vet Sci 7:53. https://doi. org/10.3389/fvets.2020.00053

Taslimi P, Gulçin I (2017) Antidiabetic potential: in vitro inhibition effects of some natural phenolic compounds on a-glycosidase and a-amylase enzymes. J Biochem Mol Toxicol 31:e21956. https://doi.org/10.1002/jbt. 21956

Worthington V (1993) Alpha amylase. In: Worthington enzyme manual, New Jersey: Worthington Biochemical Corporation, pp 36-41

\section{Publisher's Note}

Springer Nature remains neutral with regard to jurisdictional claims in published maps and institutional affiliations.

\section{Submit your manuscript to a SpringerOpen ${ }^{\circ}$ journal and benefit from:}

- Convenient online submission

- Rigorous peer review

- Open access: articles freely available online

- High visibility within the field

- Retaining the copyright to your article

Submit your next manuscript at $\boldsymbol{\nabla}$ springeropen.com 